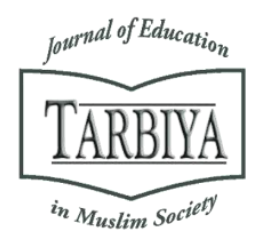

Available online at TARBIYA: Journal of Education in Muslim Society Website:

http://journal.uinjkt.ac.id/index.php/tarbiya

TARBIYA: Journal of Education in Muslim Society, 5(1), 2018, 66-77

\title{
STRENGTHENING AND TRANSFORMATION OF THE ISLAMIC EDUCATION SYSTEM IN MALAYSIA
}

\author{
Asmawati Suhid \\ Universiti Putra Malaysia, Malaysia \\ E-mail: asmawati@upm.edu.my
}

Received: $18^{\text {th }}$ March 2018; Revised: $14^{\text {th }}$ April 2018; Accepted: $28^{\text {th }}$ June 2018

\begin{abstract}
Education is an important aspect of fulfilling the mission and human development agenda. Hence, Islam places great importance in education as was stated in the first verse revealed to the Prophet Muhammad (PBUH). In Malaysia, education is also a priority in the country's development including Islamic education. The Islamic Education System in Malaysia is constantly evolving and changing to meet the needs and demands of society. Parents and societies who are increasingly interested and realized the importance of Islamic education ha created various forms and types of Islamic education. As an example, the emergence of Maahad Tahfiz, Ulul Albab programme, private Islamic Schools, Darul Quran, and the J-QAF programme showed a very encouraging improvement. Attention is also given to the children of young prisoners and married teenagers in the order they are not left behind in mainstream education. Hence, this paper, the writer will discuss three main themes; the development, strengthening, and transformation of the Islamic education system in Malaysia. To support the discussion, some research findings will be highlighted.
\end{abstract}

Keywords: islamic education system; development; transformation

\begin{abstract}
Abstrak
Pendidikan merupakan aspek penting dalam memenuhi misi dan agenda pembangunan manusia. Oleh karena itu, Islam menekankan pentingnya pendidikan seperti Firman dalam ayat pertama yang diwahyukan kepada Nabi Muhammad (SAW). Di Malaysia, pendidikan juga menjadi prioritas dalam pembangunan negara termasuk pendidikan Islam. Sistem Pendidikan Islam di Malaysia terus berkembang dan berubah untuk memenuhi kebutuhan dan tuntutan masyarakat. Orang tua dan masyarakat yang semakin tertarik dan menyadari pentingnya pendidikan Islam telah menciptakan berbagai bentuk dan jenis pendidikan Islam. Sebagai contoh, munculnya Pesantren Tahfiz, Program Ulul Albab, Sekolah Islam swasta, Darul Quran dan program J-QAF menunjukkan peningkatan yang sangat menggembirakan. Perhatian juga diberikan kepada tahanan anak-anak dan remaja yang sudah menikah agar mereka tidak tertinggal dalam meraih pendidikan pada umumnya. Oleh karena itu, dalam artikel ini penulis akan membahas tiga topik utama; pengembangan, penguatan dan transformasi sistem pendidikan Islam di Malaysia. Dalam rangka mendukung diskusi, beberapa temuan penelitian akan disorot.
\end{abstract}

Kata kunci: sistem pendidikan Islam; pembangunan; transformasi

How to Cite : Suhid, A. (2018). Strengthening and Transformation of The Islamic Education System in Malaysia. TARBIYA: Journal of Education in Muslim Society, 5(1), 66-77. doi:10.15408/tjems.v5i1.9511.

Permalink/DOI: http://dx.doi.org/10.15408/tjems.v5i1.9511

TARBIYA: Journal of Education in Muslim Society, P-ISSN: 2356-1416, e-ISSN: 2442-9848

This is an open access article under CC-BY-SA license (https://creativecommons.org/licenses/by-sa/4.0/) 


\section{Introduction}

Islam is ad-Din, Syumul (universal) and hence is a blessing to the Universe. Al Quran and the Hadith of the Prophet PBUH provide guidance for the lives of mankind as a whole. As long as mankind holds on to these two resources, their lives will not go astray on this earth and they will succeed in the Hereafter. As Rasulullah PBUH has stated:

"I leave behind me two things, the Qur'an and my example, the Sunnah, and if you follow these you will never go astray."

Indeed, ad Dinul Islam was sent down by Allah SWT equipped with all the laws and the way of life as guidance for humanity. Laws and the way of life determined by Allah SWT are in harmony with human nature. Therefore it is befitting to be practiced, regardless of time or era, by any race or nation. (Asmawati Suhid, 2009). This is because the main purpose of the creation of mankind is to realize 'ubudiyah' to Allah so that the religion can be upheld and only the word of Allah can soar high. (Ibnu Taimiyyah, Ahmad bin Abdul Halim, 1983).

Education is a tool or an important vehicle in determining the scenario and direction of a community and nation. The individuals to be be produced will also depend much on nature and the educational methodology given to the people. Apart from aiming to produce knowledgeable and skillful individuals in specific areas, education should also serve to shape and produce individuals with good character and moral values. In reality, no matter how great or highly knowledgeable and skilled the individuals are, without moral values and good character, it would result in failures in the development of a nation (Asmawati Suhid, 2014)

Therefore, education according to Islam must always be guided by these two resources namely Al Quran and Hadith, whether they are for curriculum and co-curriculum, methods of teaching, the roles, and characteristics of a teacher, the administration, management and development of the pupil. Education should not only focus on national development and unity as well as the production of human resources but, should also focus on the development of the individual as a holistic and balanced person, regarding his physical, emotional, spiritual, intellectual and also social capabilities. Thus, Islamic Education (IE) is made a compulsory subject to be taught at both primary and secondary schools aimed at producing individuals who would be righteous, faithful, abiding and of moral character. Therefore, IE must be taught as the subject of ad-Din, not merely to transmit the knowledge and skills but to be practiced and fully appreciated by every Muslim individual who has faith in Allah SWT. Based on this understanding, the role of a teacher of IE is not only to transmit information to the pupils, but also extends to the role of producing balanced and harmonious servants of Allah and khalifatullah (Vicegerent to Allah).

In this concept paper, the writer will discuss the development of the Islamic Education system in Malaysia, the consolidation process and transformation that had been and currently pursued by the Islamic Education. The writer will also highlight the research findings to provide enlightenment as well as to support the discussion.

\section{The Historical Journey of the Islamic Education Development in Malaysia}

Islamic education had begun since the time of Rasulullah (PBUH) when he received the first revelation from Allah SWT. After his passing, the Islamic education process was continued by four caliphs and his companions. Throughout the education process, there had been an incredible improvement and development until 
it reached its epoch of excellence, especially during the Ottoman era.

Briefly, the development of the Islamic Education in Malaysia could be seen through three main phases as described below.

\section{The Pre-Independence Phase}

The phase before the country gained independence, the teaching and learning of the IE was conducted in the al-Quran classes in the homes of the Ustaz or teachers and the mosques or surau. At that time, the philosophical elements emphasized in the Islamic education was the presentation of knowledge related to the reading of the al-Quran and prayers. The skill elements were also emphasized such as the skill to read the al-Quran and memorizing several short verses or surah from the al-Quran. Besides studying the al-Quran and knowledge on prayers which were widely taught, it was also reported there were studies on Fiqh, Tauhid, Tafsir, History, Sufism and Islamic philosophy but in several specific limited situations (Abdullah Ishak, 1995).

From then on, the Islamic education studies switched to a more structured form, the Pondok education system which began in the $19^{\text {th }}$ century. The education system included the beginning, middle and higher stages, as well as offering wider subjects such as Fiqh, Tauhid, Tafsir, Hadis, Islamic History, Sufism and the Arabic language (Abdullah Ishak, 1995). In the Pondok education, there was a close relationship between teachers and students based on affection and high respect. After this Islamic education era of the Pondok education system, it was followed by the madrasah education system or known as religious or Arabic schools which also encompassed the primary, secondary and higher education as offered by several madrasah. Madrasah education was seen as a form of formal education where students were grouped based on age and academic ability as well as there was the existence of the examination system. This madrasah education started with a focus on religious subjects before World War Two and subjects such as Geography, History and Arithmetic were also offered after World War Two. After the country gained independence, madrasah education offered religious subjects and academic subjects as embodied in the secondary examination level (Rosnani Hashim, 1998). Based on a broader education syllabus and not just on fardu ain and al-Quran, a more extensive Islamic Educational Philosophy was inculcated.

\section{Post Independence Phase}

The IE development after the country achieved independence, was much influenced by several education policies or education at the time such as the Razak Report 1956, the Rahman Talib Report 1960 and the Education Act 1961. The post-independence phase saw the IE included in the national education system but taught outside the school hours, that is, in the afternoon. Then, after the introduction of the Education Act 1961 or precisely in 1962, the IE subject was known as the Islamic Religious Knowledge and taught in the formal school timetable. Based on the secondary school Islamic Religious Knowledge curriculum at the time, the said curriculum was seen as imparting more on the knowledge of Islamic religion to students. This is based on the common aim of the Islamic Religious Knowledge at the time, as well as the education syllabus which focused more on the fundamentals and principles of Tauhid, Ibadat, the History of Islam, verses of the al-Quran and the hadith of the Prophet (PBUH). This was reinforced by the report presented by the Committee on the Research on the Islamic Religious Subjects in 1974 to the Cabinet Committee on Education Policy Research 1979, that is, Islamic Religious Knowledge paid less attention to practice, 
inculcation of Islam as well as the practical aspect but more on the imparting of knowledge.

Based on the Islamic Education curriculum at the time, in fact, all three aspects of metaphysics, epistemology and axiology could be identified even though the Islamic Education Philosophy was not expressed in writing.

\section{The Phase After 1988}

Following the Cabinet Committee on the Education Policy Research Report 1979 and national education was perceived as secular, the country then formed the New Primary School Curriculum (NPSC) and the Integrated Curriculum for Secondary Schools (ICSS) as well as the National Philosophy of Education statement in 1987 and the Islamic Philosophy of Education in 1988 (Rosnani Hashim, 1998).

Currently, the IE subjects reflect the Islamic Philosophy of Education that was developed. The teaching of IE does not only focus on theoretical presentations or knowledge but also the practical aspects and internalizations (Ghazali Darusalam, 2001). The changes in the Islamic Education curriculum which involved a wider syllabus, educational aims and comprehensive teaching methods and techniques resulted in the elements in the Islamic Philosophy of Education being given attention. In evidence, the IE Integrated Curriculum for Secondary schools (ICSS) encompasses three major learning areas, that is, recitation of the alQuran (Tilawah al-Quran) and Hadith, Ulum Syar'iyah as well as Islamic etiquette and character. Ulum Syar'iyah covers topics on Faith, Worship as well as the Prophet's (PBUH) Life (Sirah Nabawiyah) and Islamic Civilisation (Kementerian Pendidikan Malaysia, 2002). The statement of the National Islamic Philosophy of Education earnestly tried to present the philosophical aspects of metaphysics, epistemology, and axiology as more complete and consistent with the requirements in Islam.
In evidence, the IE curriculum clearly emphasized on aspects of faith, knowledge, character, internalization, practice as well as with the aims of producing students who believe, do good deeds, have a good personality to acquire the good life in this world and hereafter (Kementerian Pendidikan Malaysia, 1988).

\section{CONSOLIDATION OF THE ISLAMIC EDUCATION SYSTEM}

Besides the effort of improving and consolidating the Islamic Education, as described above, there were several measures taken by the Malaysian Ministery of Education. Among them are:

\section{Implementation of PAFA in schools}

The Basic Assessment Programme of Fardhu 'Ain or PAFA was introduced in the primary and secondary school levels to further reinforce the Muslim students with the basics of Fardhu 'Ain. The basics of Fardhu 'Ain (PAFA) are:

Several of the most important basics in Fardhu 'Ain, as contained in the Islamic Education Syllabus, is to determine that every pupil or student should know, understand and can correctly practice them perfectly as set by the Syara'.

The implementation of PAFA, among others, aimed to: ensure every pupil understands and able to correctly practice the Basics of Fardhu 'Ain perfectly; identify pupils who are weak in the understanding and practising the Basics of Fardhu 'Ain and guide them until they understand and able to correctly practise them perfectly; ensure there are no left-behinds in the Basics of Fardhu 'Ain; and to bring forth positive conviction and willingness to practise and internalise the Basics of Fardhu 'Ain. Comprehensive understanding should be given as early as possible so that pupils are clear and 
able to internalize the practice of worship, especially the prayers, as best as possible according to the Syariah. According to Ariffin \& Shukeri (2013), to be praiseworthy, knowledge, understanding and internalization of the prayers among Muslims are indispensable. The result will be

a generation of faqih (understanding of the fiqh) regarding the practice of worship and prayers. Therefore, in the effort to develop a generation who prays, knowledgeable and understanding is important.

\section{Introduction of $\mathrm{j}$-QAF Programme}

The IE subjects continued to evolve and improve with the existence of the $j-Q A F$ programme, which is an abbreviation for jawi, Al-Quran, Arabic language and Fardu Ain. The programme was conceived by the former fifth Prime Minister Tun Abdullah Hj. Ahmad Badawi with the aim of strengthening the acquisition of jawi, ensuring the pupils would complete the Al-Quran in the primary schools, Arab language to be made compulsory and to strengthen the practice and internalization of Fardu Ain. The $j$-QAF programme was part of an effort to empower Islamic Education and at the same time strengthening the other national education system besides supporting the Basics of Fardu Ain Assessment Programme which had been carried out previously. This programme was implemented since 2005 for primary school pupils. It is expected to be implemented in secondary schools after it is fully implemented in all primary schools and after the problem of teacher shortage in primary schools is fully resolved.

The $j-Q A F$ model implemented in schools consists of the Jawi Remedial Class Model, the 6-Months Khatam al-Quran Model, the Tasmik Model, the Arabic Language Communication Model and the Smart Camp Prayer Model. Each of these models has objectives and implementation strategies based on the modules provided. With these models, teachers would utilise the teaching techniques effectively to motivate students to learn. Among the report findings (Asmawati Suhid, 2011) from the Islamic Education teachers (IET) in Selangor regarding the $j$-QAF programme implementation are; generally, IET perceived the pupils could acquire well all the $j-Q A F$ models. Of the five models utilized by the $j-Q A F$ teachers, the Smart Camp Prayer Model (min $4.19, \mathrm{SD}=.62$ ) was mastered most by the pupils. This was followed by the Jawi Remedial Class Model (mean $=4.00, \mathrm{SD}=.66)$, the Tasmik Model (mean=3.80, SD $=.74)$, the 6Months Khatam al-Quran Model (mean= 3.78, $\mathrm{SD}=.64)$ and the the Arabic Language Communication Model (mean= 3.70, SD. .62). Regarding pupils' interests in the $j-Q A F$ models, in general, the IET viewed the pupils were interested in learning all the models utilized by the teachers. The Jawi Remedial Class Model was the pupils' most preferred model (mean= 4.37, SD =.62). This was followed by Smart Camp Prayer Model (mean $=4.30, \mathrm{SD}=.68)$, 6Months Khatam al-Quran Model, (mean= 4.14, $\mathrm{SD}=.57)$, Arabic Language Communication Model (mean $=4.01, \mathrm{SD}=.74)$, and the Tasmik Model (mean=3.89, SD = .79).

Generally, it was clear, the majority of $j$ $Q A F$ teachers were interested/very interested in all the $j-Q A F$ models that were implemented in the schools. The findings also showed on average; teachers stated the techniques used were effective and appropriate and could attract the pupils' attention. Similarly, in general, pupils were particularly keen in the j-QAF models especially the Jawi Remedial Class Model and Smart Camp Prayer Model. However, in the implementation of this programme, there were areas that were needed to be given attention in order it could run smoothly and steadily. Among others that needed to be addressed were teachers 
were less skilled in using and applying ICT in the teaching and learning process.

However, the findings by Siti Fatimah Ahmad and Ab. Halim Tamuri (2010) showed $j$ QAF teachers perceived highly the teaching aids utilization based on multimedia technology (TMm). This skill should be enhanced to ensure $\mathrm{j}$-QAF teachers; professionalism is comparable to other teachers in addition to attracting pupils to learn j-QAF subjects. The findings of the study also stated the less skilled teachers were utilizing the proposed teaching techniques in the J-QAF model especially in the application of ICT. Among the reasons or factors identified were the factors of time constraints besides the teachers were involved with other activities and tasks at schools.

\section{Implementation of the Religious Class Stream} (RCS)

The Religious Class Stream (RCS) in the day secondary schools was established upon the request of parents and the community for the education as provided at National Religious Secondary Schools (Asmawati Suhid, 2016). The existing National Religious Secondary Schools (NRSS) could not accommodate the parents' demands following the improvement in the pupils' achievement performance in the Primary School Evaluation Test (PSAT). At the same time, the Ministry of Education did not intend to increase the number of NRSS, so the need for streaming as implemented in NRSS was very much desired and hence expanded to the Normal Secondary Schools. The RCS in the National Secondary Schools was piloted in 1987. In 1992, the Religious Class Stream (RCS) was implemented in 130 schools in Malaysia. Schools that intended to open RCS were required to have hostels to accommodate pupils who lived far away from schools.

Today the rapid rise in the number of RSC is seen to meet the demands and needs of the
Muslim generation who are in the National Secondary Schools. Therefore, the implementation and quality of the RSCs should be constantly monitored and enhanced to ensure the effectiveness of the teaching and learning process of the pupils who are in this stream.

\section{The Main Stream Maahad Tahfiz}

Tahfiz education is a form of education increasingly accepted by the Islamic society in Malaysia. Tahfiz education formally began in 1966. At that time, the Huffaz Al-Quran and Qiraat Knowledge Studies were conducted in the National Mosque. The establishment was to fulfil the wishes of the first Prime Minister of Malaysia, Y.T.M Tunku Abdul Rahman Putra al-Haj. The implementation of this program received support and encouragement from various parties. From 1966 to 1978 this study or class was placed under the management of the National Mosque Governance Committee and the Secretariat of the National Council for Islamic Religious Affairs Malaysia.

In 1984, the function of the Unit of the Huffaz Al-Quran Studies was expanded to become a department of Islamic Affairs Division (BAHEIS), the Prime Minister's Department, Kuala Lumpur, known as Maahad Tahfiz alQuran wal Qiraat (MTQ) (Nordin Ahmad, 2015). The success of the MTQ could be seen when it successfully produced graduates at the diploma level and had gained recognition by the Public Service Department (PSD) when the name MTQ was changed to the Institute of Tahfiz al-Quran wal Qiraat Studies (IPTQ) (JAKIM, 2003). In 1997, IPTQ was given a new branding, i.e. Darul Quran operating under the Islamic Development Department of Malaysia (JAKIM).

Today, the increase in the establishment of the tahfiz class or school is due to the interests, demands and awareness of the parents on the importance of the al-Quran and Huffaz 
Al-Quran Studies. The Ministry of Education Malaysia also runs a tahfiz curriculum named the Tahfiz Integrated Curriculum, which is another Islamic Religious Curriculum implemented at the Government Aided Religious School (GARS) registered under the Ministry of Education. Not to lag, there is an increase in the establishment of private Tahfiz schools utilizing various forms and types of curriculum. This situation caused the tahfiz education system to be irregular and less effective. Currently, the use of technology has been applied in tahiz learning, among which is the application of Quran voice Memorizer that helps pupils in search of alQuranic index, the reading of seven qari as well as al-Quranic interpretations. In addition, there are various software known as e-Hafiz to help pupls review their readings and 'hafazan' (memorization) (Mohamad Zuwaher et.al, 2015). In reality, al-Quranic memorization needs to be addressed as it is among the mediums to ensure the al-Quranic texts are always preserved and remembered. Rasulullah (the Messenger of Allah, PBUH) when conveying the Holy al-Quran to his companions also instructed them not just to read but also to memorize its content and essence (Murihah, Arief Salleh \& Mohd Faeez, 2015).

Through JAKIM, the government is drafting a National Tahfiz Educational Policy (DPTN) for the empowerment of the Tahfiz alQuran Educational Institution in the country. It is a respond to the suggestion by the Prime Minister of Malaysia, Dato 'Seri Najib Tun Razak for the Tahfiz al-Quran Educational Institution to continue to flourish in Malaysia (Bertia Daily Online, 20 March 2016). The School or Maahad Tahfiz had received changes and improvements in the aftermaths of the recent fire tragedy of one of the central tahfiz centers involving more than 20 deaths. As a result of the tragedy, the Special Task Force of Tahfiz Schools Committee of the Highest Level, issued six recommendations about tahfiz school issues (Utusan Online, September 20, 2017). Among the important issues, the Committee recommended amendments to the Education Act 1996 (Act 550) to enable the registration of private Islamic educational institutions including the tahfiz schools to be subjected to the relevant acts.

\section{Ulul Albab Programme}

In July 2005, the Ulul Albab programme was introduced in the imtiaz secondary schools where it was combined with the learning system focusing on the al-Quran, personality development and the Secondary School New Curriculum (Asmawati Suhid, 2016). This idea was triggered when the former Prime Minister, Y.A.B. Dato' Seri Abdullah Bin Haji Ahmad Badawi was speaking at Oxford University where he mentioned and used the word Ulul Albab in his speech. The meaning of Ulul Albab refers to the group who has a strong basis in the alQuran, a broad and diverse knowledge, able to think and observe Allah's SWT creation through the soul and sharp mind and at the same time learn from it.

The main objective of implementing the Ulul Albab programme was to position the status of the state of Terengganu as a superior center of al-Quran studies in Malaysia. Besides, the Terengganu state government had provided the facilities and modern educational infrastructures for the al-Quran studies and also in the fields of science and technology to ensure that students would succeed in both areas in order to produce umatan wasatan, and this is also a continuation programme for students who are interested in the fields of science and religion as an alternative education.

Nowadays, the younger generation who will inherit the country's leadership needs to be equipped with a wide range of knowledge to be able to face the challenges of globalization and 
thus capable to uplift the country's name in the world arena and enhance the position of the Malays. The Ulul Albab programme is an integrated education programme between the existing education programme (Pure Science) and the religious programme including Tahfiz al-Quran. The Ulul Albab programme aims to produce professionals, technocrats, and entrepreneurs who are not only knowledgeable but also skillful in areas of religion based on the al-Quran and al-Sunnah as the generation of Ulul Albab.

The Ulul Albab programme maintains the existing curriculum which is implemented in all MRSM throughout Malaysia in addition to the hafazan al-Quran programme. The PMR students will take nine subjects including the Arabic language while the SPM students will take the Arabic language, al-Quran wa alSunnah, and the Islamic Syariah subjects. It is hoped that the graduates of this Ulul Albab programme will possess three main characteristics, which are:

\section{Quranic}

Memorizing the 30 juzuk (parts) in three years and understanding it based on the concepts of reading, remembering, understanding, thinking, practicing and disseminating (BIFFAS).

\section{Encyclopedic}

Knowledgeable and highly skilled, a source of reference and master the various areas of knowledge and foreign languages.

\section{Ijtihadic}

The ability to provide insights in solving the problems of the ummah, maximizing the ability to think, thinking creatively and innovatively with high technology.

The government also pays great attention to the education of teenagers who are involved in juvenile delinquency and crimes. Whatever the factors that cause them to be trapped in negative activities, they still need to be defended regarding education for their future. What is even more alarming, they are the inheritors or the determinants of the country's future leadership where more than $50 \%$ of the registered voters are those in generation $Y$. There should not be any accusations or pointing fingers to any party. Each of us is responsible in playing the appropriate role according to each's capability. Thus, the government has taken the initiatives to set up Integrity schools that place young prisoners where they can acquire knowledge and skills to prepare themselves upon discharge and back to the community. Likewise, there are also teenagers who are married due to certain factors and reasons. They should not quit schools simply because they are married, in fact, they need to think of education for themselves.

\section{ENHANCEMENT AND TRANSFORMATION OF THE ISLAMIC EDUCATION SYSTEM}

The philosophy of education in Islam demonstrates that it is universal, comprehensive, balanced, global and very comprehensive as a foundation that can guide and give guidance to the people in forming the direction of the educational system that can be implemented. The philosophy of Islamic Education according to as-Syaibani as explained by Ahmad Mohd. Salleh (2004) is bound to certain elements and conditions, namely,

1. should be suitable to the soul of the Islamic faith and laws.

2. should be related to the cultural, social, economic and political reality of the society.

3. should be based on the relevant aspects of the human life related to knowledge and its branches and the experiences of humanity.

4. should be universal based on social, cultural, economic, political, educational, psychological factors and others. 
5. Should have selective characteristics suitable to the soul of Islam.

6. Should be free from contradictions or conflicts between principles and beliefs which become the basis between the principles and the practical implementation.

7. Should be based on clear examples.

8. Should be dynamic, developing, relevant to studies and research developments in various fields.

Based on the elements and bound to the educational philosophy of Islam above, it is clear that it is comprehensive, holistic, dynamic and universal. The philosophy of education according to the Islamic view is based not only on human thoughts but also on Allah's SWT edicts. A Philosophy that is not based on divinity and faith in Allah SWT will certainly be unbalanced and headed towards failure. Thus, the educational philosophy in Islam that is comprehensive, holistic, and balanced emphasizes the following concepts (Mohd. Kamal Hassan, 1987); which includes lifelong education; the development of full potentials (soul, mind, and body), integrated, including the cognitive. Affective and volitional aspects; delivering two functions, as servants to Allah SWT and as Allah's SWT khalifah on earth; prosper the whole world; the integration and perfection of faith, knowledge and good deeds; and happiness in this world and hereafter.

It is clearly shown that the Islamic educational philosophy strives to achieve and to realize the aim of producing individuals who believe, pious, materially and spiritually balanced and threin enlightens the world of Allah SWT according to the Islamic laws (Asmawati Suhid dan Fathiyah Fakhruddin, 2012). Based on the Philosophy of Islamic Education (FIE), IE in Malaysia also inculcates the FIE's inspiration in developing and enhancing the IE's status and system. To date, the summit is achieved when IE is involved in the National Education
Transformation Plan. Therefore, it is clear that IE is constantly following the flow of development in the national education system. Educational transformation can be assessed through the current learning and developmental stages of the pupils. Changes in the pupils' learning can be seen by the ministry's approach to education focusing on the holistic pupils' development that emphasizes on the intellectual, spiritual, emotional, and physical development, together with the building of strong national identity (Malaysian Education Development Plan, 2012). According to the Malaysian Education Development Plan (2012), the Ministry will ensure the implementation of an integrated curriculum based on the international benchmarks to produce pupils with the skills required to compete globally. This curriculum will touch on every pupil's intellectual, spiritual, emotional, and physical dimensions, and emphasizing on the application of knowledge and critical thinking, creativity, and innovative thinking development.

The curriculum transformation was further enhanced by the implementation of the Primary School Standard Curriculum (PSSC) replacing the New School Curriculum (PSNC). Likewise, the Islamic Education subjects core subjects for the Muslim pupils must be taught in Educational Institutions with at least 5 Islamic students. The transformation of the curriculum emphasizes the use of various teaching and learning approaches that provide more emphasis on hands-on learning such as discovery by inquiry, problem-based learning, constructivist learning, contextual learning, self-regulating learning, master learning, and classroom outdoor learning. The approaches used must provide fun learning opportunities for the pupils, taking into account their intellectual diversity.

Therefore, IE teachers should always be prepared to improve pupils' knowledge and skills so their learning would not be unaffected and 
left behind in the mainstream. However, it is important to note that education and moral character development should not be sidelined solely to meet the globalization and digital era. This is because human development is the key to the success and prosperity of a nation.

\section{ISLAMIC EDUCATION SYSTEM IN FACING CURRENT CHALLENGES}

In heading towards success and excellence, there are challenges and obstacles that must be faced and overcome with wisdom and efficiency. Similarly, the Islamic Education system has various challenges that need to be addressed wisely and collectively. Therefore, Muslims must be willing for a paradigm shift especially in understanding the philosophy and concept of education that fulfills the ideal and practical Islamic characteristics that are dynamic at all times. Firstly, Muslim educators should always be prepared to accept changes in the education system. Moreover, the present generation is now exposed to various phenomena as a result of the globalization explosion and the rise of the digital era. They are exposed to the use and application of modern and sophisticated Information Technology and Communication (ICT) smart devices. Do not let things happen where pupils are more 'sophisticated' than teachers. As according to Noor Fadlina (2014) and Kamarul Azmi et al. (2011), teachers' weakness in the mastery of knowledge, PdPC's methodology, the use and application of Information Technology and Communication or ICT in education are among the factors detected in education in schools. Therefore, PI teachers should acquire the ability to integrate the $21^{\text {st }}$-century skills and innovation in teaching if they want to produce pupils with living skills, be competitive, creative and innovative. Hence, teachers need to be equipped with the 21 st-century knowledge and teaching skills without neglecting the values, principles and traditional Islamic education characteristics which have successfully produced the great Islamic scholars and 'ulamak'.

Similarly, teachers need to understand and skillful in applying higher order thinking or (HOTS) in the teaching and learning process (T\&L) to develop pupils" creativity and innovation to the optimum level. Besides HOTS, teachers also need to train and guide pupils in reasoning for them to solve problems they encounter. Besides, the issues faced by IE teachers are those who lacked understanding in the content of the Curriculum and Assessment Standard Document (CASD). They were found to be confused over the differences between CASD and the Subject Syllabus Description which ultimately led to a misunderstanding or misinterpretation of CASD's concept and goals (Asmawati Suhid, 2016). Teachers should have the ability to integrate 21 st-century skills such as mastering teaching methods or techniques that emphasize Hands-on Learning, inquiry learning and mixed learning to produce pupils possessing life skills and competitive, creative and innovative. Therefore, teachers need to be wise in selecting methods and approach appropriate to the situations and needs of the pupils for it is one of the important factors in determining the effectiveness of teaching and learning. According to Ahmad Mohd. Salleh (1997), the suitability of the teaching approaches is closely related to the type of pupils and of teachers' teaching.

Besides the Islamic education system under the Federal Government, there is also an Islamic education system placed under the jurisdiction of the states that adopts different curricula between the states and the mainstream curriculum. Among them are the State Religious Schools (SRS), the People's Religious Schools (PRS), and the school or maahad tahfiz. Also, the KAFA programme or the Quranic and Fardu Ain classes were introduced in PRS. All of these schools are coordinated by the Islamic Education 
and Education Coordination Advisory Board or LEPAI under the Department of Islamic Development Malaysia (JAKIM) established by the Rulers"s Council. LEPAI is given the responsibility to coordinate and promote Islamic Education in Malaysia.

Based on interviews with several figures and research on documents in the Malaysian Islamic Affairs Improvement Taskforce Review (2016), researchers found that there are aspects that need to be improved and enhanced such as in terms of LEPAI's administration, inter-state interactions with the Federal Government, diversity in forms of education and those that are not uniform, the emergence of uncontrolled religious school, as well as overlapping with mainstream Islamic Education. Therefore, these situations need to be addressed, and the coordination of LEPAI should be strengthened for a strong Islamic education system for the sake of the sovereignty of Islam in Malaysia.

\section{Conclusion}

Based on the above discussion, the holistic and collective involvement of various parties is very important to ensure that the desire to enhance and strengthen the Islamic Education system in Malaysia are achieved. Parents as role models should and even must inculcate the Islamic values in the family so that individuals are born with a strong faith and taqwa (piousness and God-fearing) to Allah swt. No less important is the role of the teachers as models for they are supposed to be the murabbi, muad'dib, and mu'allim to the school children. Teachers should shoulder responsibilities and be aware of their duties as trusted upon them by the parents and communities. The school environment and infrastructure must be decorated with Islamic values and biah, including ensuring cleanliness, dress codes of the school community, the daily practice inculcated in the lives of the school children, fair and transparent management and good relationships between the members of the school community. However, it is imperative for the government or the leaders to play a part in helping and supporting the earnest efforts of all parties to ensure what is planned and desired are achieved. Those involving policies and regulations need to be examined in detail, transparent and scrutinized in more depth taking into account the views of all parties.

\section{References}

Ahmad. Siti F., Tamuri, Ab. H. (2010). Persepsi guru terhadap penggunaan bahan bantu mengajar berasaskan teknologi multimedia dalam pengajaran j-QAF. Journal of Islamic and Arabic Education 2(2),2010,53-64.

Darusalam, G. (2001). Pedagogi Pendidikan Islam. Kuala Lupur: Utusan Publications $\&$ Distributors.

Hassan, Mohd. K. (1987). Peranan akhlak dalam pendidikan. Jurnal Pendidikan Islam. Bil. 8: 3

Ishak, A. (1995). Pendidikan Islam dan pengaruhnya di Malaysia. Kuala Lumpur: Dewan Bahasa dan Pustaka.

Jasmi, K. A., Ilias, M. F., Tamuri, Ab. H., Mohd. Izham Mohd. Hamzah (2011). Amalan penggunaan bahan bantu mengajar dalam kalangan guru cemerlang Pendidikan Islam Sekolah Menengah di Malaysia. Journal of Islamic \& Arabic Education, 3 (1), Hlmn. 59-74.

Mamat, A., Mohamad, S. (2013).faqihan dalam membentuk generasi solat. Jurnal Keputeraan. Model masyarakat bertaqwa, jilid 2, 2013. 
Murihah, A. S., Faeez, M. (2015). Pendidikan tahfiz di Malaysia: Satu sorotan sejarah. Kertas kerja yang dibentangkan di International Conference on Islamic Education and Social Entrepreneurship di Resort World Langkawi, tanjung Malai, Langkawi pada 12 hingga 14 Oktober 2015.

Nawawi, N. F. (2014). Hubungan antara pengajaran dan pembelajaran, keperibadian dan kemahiran guru Pendidikan Islam dengan motivasi pelajar. Tesis, Universiti Teknologi Malaysia. Tidak diterbitkan.

Radzi, M. S. M., Hamzah, R., Udin, A., (2011). Menyelesaikan masalah pembangunan akhlak pelajar: Analisis penerapan kemahiran generik dalam amalan pendidikan. Journal of Edupress. 1(1), 223-229.

Rosnani, H. (1998). Ke arah perindustrian negara Islam berasaskan moral dan nilai. Jurnal Pendidikan Islam, Jilid 8, Bil.1 Mac.

Salleh, A. Mohd. (2004). Pendidikan Islam. Falsafah, pedagogi dan metodologi. Shah Alam: Penerbit Fajar Bakti Sdn. Bhd

Suhid, A. (2009). Pendidikan Akhlak dan Adab Islam. Kuala Lumpur: Utusan Publications \& Distributors Sdn. Bhd.
Suhid, A. (2011). Program j-QAF: Cabaran kini, harapan masa depan. Kertas kerja yang dibentangkan di Kongres Pendidikan Islam Kebangsaan 2011, Hotel Dynasty Kuala Lumpur, 4-7 Disember 2011.

Suhid, A. (2014). The Roadmap of Islamization of Educational System in Postcolonial Era. Paper presented at Ar-Raniry University, Acheh, Indonesia, 20 - 21 August 2014.

Suhid, A. (2016). Transformasi Kurikulum Pendidikan Islam dalam sistem pendidikan kebangsaan: Isu dan cabaran. Kertas kerja dibentangkan di International Conference On Islamic Education 2016 (ICIED 201), di Kuching, Sarawak, 5-7 Oktober 2016.

Suhid, A., Fakhruddin, F. (2012). Gagasan pemikiran falsafah dalam Pendidikan Islam: Hala tuju dan cabaran. Journal of Islamic and Arabic Education, Issue 4, Vol. 2, 2012.

Taimiyyah. I, Ahmad bin Abdul Halim (1983). Al-Ubudiyyah. Beirut : Al-Maktab alIslami.

Zuwaher, M. S., dkk. (2015). Dalam Mohd Zaini Zakaria, dkk (Ed), Memasyarakatkan Quran mensejahterakan ummah. Bandar Baru Nilai: Fakulti Pengajian Quran dan Sunnah. 